\title{
THE DEVELOPMENT OF LEARNING MEDIA AND CRITICAL THINKING SKILL INSTRUMENT BASED ON 5E LEARNING CYCLE MODEL ON HARMONIC VIBRATION MATERIAL
}

\author{
Malahayati Rahayu Sulastri", Jannatin 'Ardhuha, and Muhammad Zuhdi \\ Physics Education Department, FTTE, University of Mataram, Mataram, Indonesia \\ *Email: malahayatirs17@gmail.com
}

Acceped: August 27 2021. Approved: Sept 01 2021. Published: Sept 042021

\begin{abstract}
This study aims to produce products in the form of learning media and instruments based on the $5 \mathrm{E}$ learning cycle model on harmonic vibration material. It is development research using the ADDIE model consisted of 5 stages: analysis, design, development, implementation, and evaluation stages (this study was limited to the development stage). The products developed were Syllabus, Lesson Plan, Student Worksheets, and Critical Thinking Skill Instruments in Physics. The feasibility of the learning media and instrument developed was measured by three experts' validation by calculating the validity and reliability values of the media and instrument. The validity results based on the experts' assessment showed that the score of the syllabus was 3.70 with very valid criteria. The Lesson Plan was 3.66 with very valid criteria; the LKPD was 3.66 with very valid criteria, and the Critical Thinking Skill Instrument in Physics was 3.63 included in the very valid criteria. The reliability results of the syllabus were $94.52 \%$, the Lesson Plan was 90.36\%, the LKPD was 91.78\%, and the Critical Thinking Skill Instrument in Physics was 93.62\%, indicating that all aspects assessed had a reliable category. Based on these results, it can be concluded that the learning media and instrument developed are feasible to use in learning to improve students' critical thinking skills in Physics on harmonic vibrations material.
\end{abstract}

Keywords: development of learning media and instrument, 5E-learning-cycle model, critical thinking skill, harmonic vibration

\section{INTRODUCTION}

Education is a process to fix, change, and improve the knowledge and skill of the students to a better future. Education is expected to guarantee students have skills in learning and create innovation in the future. Education is also inseparable from the learning process. The learning process is an interaction between students, teachers, and learning sources in an educative environment [1]. This learning process continues to changes, and it is known in learning as 21 st-century skills.

The 21st-century skills have become very important for students to master. According to Wagner [2] and Change Leadership Group from Harvard University, the 21st-century skills are skills needed by students for living, seeking a job, and being people in the 21 st centuries emphasizing seven skills: critical thinking and problem solving, collaborative skill, and leadership, agility, and adaptive skills, initiative and entrepreneur skills, oral and written communicative skill, accessing and analyzing information, and willing to learn and be imaginative. However, the learning process in Indonesia does not encourage the development of critical thinking skills [3]. Learning is still oriented on the ability to memorize information from the teacher. One of the factors causing the low critical thinking skill is less innovation done in preparing the learning media and instrument.

Achievement in 21st-century skills is possible by developing student-centered learning methods [4]. One of the student-centered methods is the 5 E learning cycle. Students do a series of activities to master competencies needed by actively participating in the learning process [5]. It is one of the learning models with a constructivist approach, seeing from implementing the five stages of learning: engagement, exploration, explanation, elaboration, and evaluation [6].

An interview with a Physics teacher of SMAN 7 Mataram on January 13, 2020, showed that the learning process is still teacher-centered. Conventional learning models still dominate learning activities, so the expected good interaction between teachers and students is still limited. However, discussions and practicums are sometimes used by the teachers. The teachers claimed that the implementation of studentcentered learning had not been optimally conducted. In addition, there has never been development research related to using the $5 \mathrm{E}$ learning cycle model to improve students' critical thinking skills in Physics. Thus, this development research is considered essential to conduct.

In addition to the reasons above, the Covid-19 pandemic that changed the face-to-face learning system to online learning also made students unable to receive full learning. If this continues, it will have an impact on the ability of students. Thus, an alternative is needed in the form of developing learning tools and instruments for critical thinking in Physics that can assist teachers in planning learning for students and facilitate students to improve their critical thinking skills in Physics by applying the 5E learning cycle model.

The 5E learning cycle model facilitates conceptual, which potentially develops each individual [7]. Students at the explore stage are 
required to analyze the concept of material, apply the idea to a new situation at the elaboration stage, and evaluate each time learning is conducted at the evaluation stage. Therefore, through this model, students' critical thinking skills can be increased.

Based on the explanation above, a learning model to improve students' critical thinking skills in Physics is needed. Developing learning tools and instruments for critical thinking skills in Physics based on the 5E learning cycle model, students' critical thinking skills in Physics are expected to improve, especially during the Covid-19 pandemic.

\section{RESEARCH METHOD}

It is development research, and the subjects were in the form of learning media and instruments for critical thinking skills in Physics. The learning media included syllabus, Lesson Plan, and student worksheets $(L K P D)$, while the instrument was a question of evaluating students' critical thinking skills in Physics. The learning media and instrument developed were designed based on the syntax of the $5 \mathrm{E}$ learning cycle model, which consists of preparation, exploration, explanation, elaboration, and evaluation. It can train students' critical thinking skills in Physics and be adapted to the five critical thinking indicators by Facione [8], i.e., interpretation, analysis, evaluation, inference, and explanation.

The research design used was the ADDIE model development design from Dick and Carry, which consists of analysis, design, development, implementation, and evaluation [9]. The development stages of the ADDIE model are shown in the following figure.

The implementation of this research was limited to the development stage, i.e., the validity test to determine the feasibility of the product developed. Due to the Covid-19 Pandemic situation, which has stopped all face-to-face teaching and learning activities in Indonesia, replaced by online learning at their respective homes.

Analysis of the research data was done by using validity and reliability tests. The reliability test was to determine the feasibility of the product, while the reliability test was to determine the level of determination of values between validators.

1. Validity Test

This test had four answer choices according to the Likert scale: 4 stating strongly agree, 3 stating agree, 2 stating less agree and 1 stating disagree. Thus, the total score of the assessment can be found using the following equation.

Total score $=\frac{\text { instrument score }}{\text { maximum score }} \times 4$

The total score results were averaged with the accumulated scores of three expert lecturers to determine the feasibility of the product developed. Suyanto [10] then classifies the average score of the validation results as the following table shows.

Table 1. Classification of validation result

$$
\begin{aligned}
& 3.26-4.00 \\
& 2.51-3.25 \\
& 1.76-2.50 \\
& 1.01-1.75
\end{aligned}
$$

\section{Reliability Test}

The reliability test uses the Borich method, known as the Percentage Agreement (PA). The percentage of agreement between evaluators is the percentage of the suitability values between evaluators. The Borich method was used for 2 validators, so the analysis was conducted by combining the 2 validators resulting 3 combinations of validator pairs. For each PA values, the average value of the combination between validators was taken. The percentage agreement (PA) according to Lestari [11] can be formulated as follows.

Percentage Agreement $(\mathrm{PA})=\left(1-\frac{A-B}{A+B}\right) 100 \%$

$\mathrm{A}$ is the higher score, and $\mathrm{B}$ is the smaller score. The larger score (A) is always subtracted from the smaller score (B). The instrument is reliable if the percentage value of the agreement is more or equal to $75 \%$. If it is less than $75 \%$, it should be tested for clarity and approval from the observer [12].

\section{RESULT AND DISCUSSION}

Analysis Stage

The analysis stage is gathering information by analyzing the need to develop learning media and instruments. The process of performance analysis, student analysis, concept analysis, and learning objectives analysis was conducted as described as follows.

\section{a. Performance Analysis}

Performance analysis is an activity conducted to find out the problems faced in learning Physics. This analysis was done by conducting interviews with the Physics teacher of Class X IPA 3 at SMA Negeri 7 Mataram. The interviews conducted on January 13, 2020, showed that learning activities in the classroom are still centered on the teacher, dominated by conventional learning models, and occasionally use other learning models. The teacher also mentioned that student-centered learning activities could not be fully implemented.

\section{Students Analysis}

Student analysis is a study of the characteristics of students based on their knowledge, aiming at determining the students' critical thinking skills in Physics. Observations made to students of Class X IPA 3 at SMA Negeri 7 Mataram on January 15, 2020, showed that students' scores in Physics subject were still relatively low based on the scores of the MidSemester Examinations, where most of the 
students scored below the Minimum Completeness Criteria $(K K M)$.

\section{Concept Analysis}

Concept analysis identifies the main concepts to be taught so that they are relevant to learning media and instruments for critical thinking skills in Physics on harmonic vibration material. The concepts in the material of harmonic vibrations included: the definition of simple harmonic vibrations, physical quantities in harmonic vibrations, vibrations, period, frequency and time in harmonic vibrations, period and frequency relationships, deviation, velocity, acceleration, kinetic energy, potential energy, and energy, mechanics, and the application of harmonic vibrations in everyday life.

b. Analysis of Learning Objectives

Analysis of learning objectives is necessary to determine the competencies that students must possess in learning, especially in the material of harmonic vibrations. The formulation of learning objectives is based on core competencies and basic competencies of the 2013 Curriculum on harmonic vibration material and adapted to learning indicators.

\section{Design Stage}

The design stage aims at designing learning media and instruments based on the 5E learning cycle model and research instrument. The learning media developed were syllabus, Lesson Plans, and Student Worksheet $(L K P D)$. The instrument was a question instrument based on the learning cycle 5E model to improve students' critical thinking skills in Physics. The research instrument compiled was in the form of a validated questionnaire for learning media and instruments. The following are the results of the product design developed in this study.

\section{Syllabus}

The syllabus is used as a reference for preparing Lesson Plan, which includes core competencies, basic competencies, basic materials, learning activities, assessments, time allocation, and learning resources developed according to graduate competency standards and 2013 Curriculum content standards. The selection of material sources in this syllabus was from Class $\mathrm{X}$ books and University books at the Fundamental Physics level that correspond to harmonic vibrations. The syllabus was prepared based on the $5 \mathrm{E}$ learning cycle model by modifying the existing syllabus and adding indicators, assessments, time allocation, and learning resources at each meeting.

\section{Lesson Plans}

The Lesson Plan with the 5E learning cycle model is a learning scenario that will guide the teacher. The Lesson Plan developed consists of core competencies, basic competencies, indicators, learning objectives, learning resources, learning media, learning steps, and assessment techniques for each meeting. There were three meetings in the developed Lesson Plan. The first meeting discussed the matter of Physical quantities on harmonic vibrations and the concept of harmonic vibrations, the second meeting discussed harmonic vibration equations and period and frequency relationships, and the third meeting discussed energy in harmonic vibrations. The learning activities applied in the Lesson Plans were adapted to the syntax of the 5E learning cycle model, which consists of preparation, exploration, explanation, elaboration, and evaluation, which could train students' critical thinking skills in Physics. The process of learning activities with the 5E learning cycle model is expected to run based on the plan been designed so that learning objectives can be achieved optimally.

\section{Students Worksheets (LKPD)}

Students Worksheets (LKPD) are prepared based on competency achievement indicators at each meeting, adapted to the $5 \mathrm{E}$ learning cycle model. There are 3 LKPDs developed, experimental $L K P D$ at meeting 1 and meeting 2, and $L D P D$ discussion at meeting 3 which contains questions related to the material of harmonic vibration. In general, the LKPDs contained the title, student identity, instructions for using the $L K P D$, and questions that later were filled by students, adapted to the indicators of critical thinking skills in Physics so that students are accustomed to sharpening critical thinking skills in every meeting. In addition, the questions developed are adapted to more contextual materials so that students are more interested in analyzing answers on the $L K P D$.

\section{Physics Critical Thinking Skill Instrument}

The instrument developed was used as an evaluation tool to measure students' critical thinking skills in Physics. This instrument was in the form of a description consisted of seven questions based on indicators of critical thinking skill according to Facione [8]: interpretation, analysis, evaluation, inference, and explanation. The first, second, and sixth questions consist of interpretation, analysis, evaluation, inference, and explanation indicators. While the third question consists of indicators of interpretation, analysis, and evaluation. The fourth, fifth, and seventh questions consist of indicators of interpretation, analysis.

5. Data Collection Instrument Design

The data collection instrument was a validation sheet used to determine the feasibility of the learning media and instrument developed. This validation was conducted by three Physics lecturers who are experts in the field of Physics called expert validators. Validation was also 
conducted to get suggestions for improving the learning media and instrument that had been developed. The validation sheets in this study were syllabus validation sheets, Lesson Plan validation sheets, LKPD validation sheets, and instrument validation sheets. While the scale used to compile the validation sheet is using 4 Likert scales: $4=$ strongly agree, $3=$ agree, $2=$ less agree, and $1=$ disagree.

\section{Development Stage}

The development stage is the stage to produce a product that the expert validators have validated. Validation was conducted to obtain assessments and input related to learning media and instruments having been designed. This stage is also intended to determine the feasibility of the learning media and instrument development.

The results of the validation of learning media can be seen in Table 2 . While the reliability analysis of the products having been developed based on the validation results can be seen in Table 3 .
Table 2. Validity Test Results

\begin{tabular}{lcc}
\hline \multicolumn{1}{c}{ Product } & Average Values & Category \\
\hline Syllabus & $3 . .70$ & Very valid \\
Lesson Plan & 3.66 & Very valid \\
LKPD & 3.66 & Very valid \\
Instrument & 3.63 & Very valid \\
\hline
\end{tabular}

The validation of learning media and instruments based on experts' assessments shows that the four products developed, the syllabus, Lesson Plan, LKPD, and Physics critical thinking skills instrument are in the very valid category with several revisions to make the product better. Furthermore, a reliability test was conducted based on the value obtained in the validity test using the percentage agreement method to determine the level of determination of the product developed. The results of the reliability test are presented in Table 3.

Table 3. Media Reliability Results

\begin{tabular}{lccccc}
\hline Products & \multicolumn{3}{c}{ Validators' PA Values } & \begin{tabular}{c} 
Average \\
Percentage \\
\cline { 2 - 4 }
\end{tabular} & \multicolumn{2}{c}{$\mathbf{V}_{\mathbf{1 - 2}}$} & \multicolumn{2}{c}{$\mathbf{V}_{\mathbf{1 - 3}}$} & Category \\
Syllabus & 91.43 & 94.64 & 97.50 & 94.52 & Reliable \\
Lesson Plan & 90.41 & 92.06 & 88.62 & 90.36 & Reliable \\
LKPD & 91.50 & 93.79 & 90.05 & 91.78 & Reliable \\
Instrument & 92.26 & 93.65 & 94.97 & 93.62 & Reliable \\
\hline
\end{tabular}

This study aims at producing learning media and instruments based on the 5E learning cycle model to improve students' critical thinking skills in Physics suitable for use in learning, especially on harmonic vibration material. After the product was developed, the product was validated by expert validators to measure its feasibility.

\section{The Validity of Learning Media and Physics Critical Thinking Skill Test Instruments}

1. Syllabus Feasibility

The syllabus developed was compiled with reference to the 2013 Curriculum, covering several components such as core competencies, basic competencies, basic materials, indicators, time allocations, assessments, and learning resources. Appropriate learning media are a collection of learning media that meet valid criteria based on assessments by experts [13].

Based on the results of the data analysis, the syllabus has an average value of 3.70, which indicates that overall, the syllabus developed based on the experts' judgment has validity with very valid criteria. The validators gave some inputs for the better products: (1) adding indicator "to analyze the relationship between force and vibration in everyday life", (2) adding practicum tools on sources and learning, and (3) improving writing that is not precise to the syllabus. In terms of content and construction, improvement is also needed.

2. Lesson Plan Feasibility

The Lesson Plan preparation was derived from the syllabus and later used as a guideline in conducting learning activities, hoping that the material can be presented systematically and the learning objectives formulated can be achieved. The components contained in the Lesson Plan include subject identity, core competencies, basic competencies and indicators, learning objectives, teaching materials, time allocations, learning models, learning approaches, and learning resources.

The lesson plan based on the 5E learning cycle model means that learning activities are conducted using the model's syntax, which consists of engagement, exploration, explanation, elaboration, and evaluation. This model was used because as students are required to analyze the concepts in a material at the explore stage, then apply the concepts to new situations at the elaboration stage, and finally conduct an evaluation at each time learning at the evaluation stage is believed to be able to increase the students' critical thinking skill. 
The teacher's learning objectives described the engagement stage in the Lesson Plan in accordance with the learning objectives at each meeting. The learning objective of the first meeting is to explain the understanding and concepts of harmonic vibrations, including the quantities that arise in objects that move harmoniously. As motivation, the teacher demonstrates a pendulum that moves from left to right past its equilibrium point. Through these activities, students could be more excited and interested when they see the phenomena displayed.

In the exploration stage, the teacher divided students into several heterogeneous groups. The opportunity for group discussion began at this stage. The teacher then instructed all students to read the LKPD. Meanwhile, the exploration stage was marked by the teacher instructing students to start the experiment and answer the questions in $L K P D 1$ by looking from books or other sources of information. The teacher was tasked with guiding students to conduct experiments and discussions and directing students in processing data from observations. Next, students together with group members, answer the questions on $L K P D 1$.

The elaboration stage in the Lesson Plan of the first meeting was a result presentation activity. The teacher-directed each group to present the results of the discussion in accordance with $L K P D 1$. In contrast, the other groups provided responses and rebuttals about the material of harmonic vibrations that they feel need to be improved. Then, the teacher provided reinforcement and correction of the results of observations and discussions that had been conducted. The last stage was the evaluation stage, the teacher asked questions to students to check students' understanding of the material that had been delivered.

The engagement stage of the second meeting was in the form of delivering the learning objectives, "Analyzing the relationship between period and frequency on objects that move harmoniously". The teacher motivated students by asking apperception questions, "What will happen when a load is hung on a spring then the spring is pulled and released slowly." In the exploration stage, the teacher again divided students into several heterogeneous groups. Discussion activities at this stage were by conducting experiments related to pendulums and springs.

The elaboration stage in Lesson Plan of the second meeting was in the form of presentation activities. The teacher-directed each group to present the results of the discussions conducted. In contrast, the other groups provided responses and rebuttals about the material equations on harmonic vibrations that they felt need to be improved. The teacher then provided reinforcement and corrections regarding the results of the observations and discussions.

At the third meeting, material about energy in harmonic vibrations was discussed. The engagement stage at the meeting was marked when the teachers conveyed learning objectives related to the energy possessed by objects that move harmoniously. Students sat with groups in the exploration stage to then answer any questions contained in the LKPD. The teacher then directed students to present the discussion results in front of the class at the elaboration stage, while the other groups listened and provided responses regarding the delivery of the results of the discussion.

Before analyzing the validation results, the Lesson Plan had to be corrected by the suggestions and inputs from each validator. Fatmawati [14] stated that the assessments and suggestions given by the validator were used as input and the basis for revising the learning media. Several things need to be improved in the development of the Lesson Plan, such as providing apperceptions with higher question portions, adding indicators at the first meeting, and changing questions in apperceptions at the second meeting. In addition, several things need to be reviewed based on input from expert validators, including revising the selection of operational verbs and the writing of "harmonics" that are still wrong.

The results of the validation analysis by expert validators have an average value of 3.66 . This value is categorized as valid with revisions according to the suggestions given by each validator. The validity of a media, in this case, is the Lesson Plan, which shows that this media is suitable to be used in improving critical thinking skills in Physics. The feasibility of the Lesson Plan can also be strengthened by learning activities that facilitate students to develop critical thinking skills following the exploration and elaboration syntax.

3. Student worksheets $(L K P D)$ Feasibility

Student worksheets (LKPD) are media that can be used to assist and facilitate teaching and learning activities. The developed student worksheets were used to facilitate and train students to develop their critical thinking skills. Andriyatin et al. [15] said that LKPD must be designed using the existing approach in the learning cycle made, starting from apperception activities to evaluations used for one activity. Students are more active in learning activities.

The LKPD developed consisted of experimental and discussion worksheets, which are equipped with instructions and working steps, and adapted with indicators of critical thinking skills to help train students' abilities. Each meeting was equipped with one $L K P D$, meaning that each $L K P D$ was prepared based on the material presented at each meeting. The feasibility of the $L K P D$ based on the average value of all validators is 3.66, which means that the $L K P D$ is very valid with revisions according to the suggestions given. The advice given is to add questions in the LKPD, and/or $L D P D$ that can train, hone and develop students' critical thinking skills in Physics. LKPD 
is also expected to be in accordance with the learning experience of students. The average validity value of 3.66 (valid) meansthat the LKPD is feasible to improve students' critical thinking skills in physics.

4. Physics Critical Thinking Skill Instrument Feasibility

Physics critical thinking skill instrument is a media used to measure students' critical thinking skills in Physics. The instrument was made in the form of descriptive questions consisting of 7 questions. Each question was arranged based on indicators of critical thinking skills in Physics [8].

The validator gave validated instruments suggestions and input to add one or two more complex questions and require analysis for students. Instruments are also expected to be concise, clear, and easily understood by students. These suggestions are then used as the basis for revising the developed products to be better. Based on the validation results, the average value of the four validators is 3.63 , with a very valid category. The instrument's feasibility shows that the developed test can measure students' critical thinking skills in Physics.

In addition to the validity test, the learning media and instruments developed were also tested for reliability. Reliability means that an instrument is quite reliable as a data collection tool because the instrument is already good [16]. Reliability in this study means that the validation results have a determination between validators. Media reliability was analyzed using the Borich method by looking at the percentage agreement value, which shows the agreement value between validators.

\section{Reliability of Learning Media and Instrument of Students' Critical Thinking Skill in Physics}

\section{Syllabus Reliability}

The syllabus is not only analyzed for validity but also reliability. Reliability is a test that shows the value of agreement between validators. A media is said to be reliable if the average value of the percentage agreement is above or equal to $75 \%$. The average value is determined by combining the validation results by the three expert validators, then the average value of the percentage agreement is determined. The percentage agreement value in the syllabus is $94.52 \%$, with a reliable category, this shows that the percentage agreement between validators reaches $94.52 \%$.

\section{Lesson Plan Reliability}

Lesson Plan reliability based on the percentage agreement value is $90.36 \%$. This value means that the Lesson Plan is reliable because the PA is above $75 \%$. Lesson Plan reliability shows that the agreement regarding each question item on the validation sheet between expert validators reaches a value of $90.36 \%$.

3. Student Worksheets (LKPD) Reliability

In addition to the feasibility or validity test, the $L K P D$ developed is also determined for its reliability. $L K P D$ reliability is $91.78 \%$, so that $L K P D$ can be said to be reliable. The reliability of the $L K P D$ shows that the agreement between validators reaches $91.78 \%$, which indicates that the validators agree that in terms of content and structure, the developed worksheets can be used to facilitate students in developing critical thinking skill in Physics.

4. Instrument of Critical Thinking Skill in Physics Reliability

Reliability is an important thing in the preparation of the instrument. The instrument that has been developed is then assessed by a team of experts and becomes the basis for determining the value of the percentage agreement (PA). The PA value for the Physics critical thinking skill instrument is $93.62 \%$ which is greater than $75 \%$, so the instrument can be reliable. Respectively, the acquisition of reliability scores for the syllabus, Lesson Plan, $L K P D$, and critical thinking physics instruments was $94.52 \%, 90.36 \%, 91.78 \%$, and $93.62 \%$. Thus, the product developed can be declared reliable because it has a value percentage agreement above $75 \%$.

Research on the development of this R\&D model was carried out until the development stage, producing output products in learning media and instruments based on the 5E learning cycle model based on validity tests by expert validators. The implementation and evaluation stages were not carried out due to the pandemic conditions, making it impossible to conduct face-to-face research with students. According to Sugiyono [17], development research has 4 levels. The first level is only to produce designs, not proceed with creating products and testing them. The second level does not do product development but directly tests existing products. The third level develops a current product and tests it. The fourth level researchers research to create new products and test the effectiveness of these products. So, this development research is level 3 development research, developing existing products such as syllabus, Lesson Plans, LKPD, and instruments and then testing their feasibility. The development research carried out up to the development stage has also been carried out by Dewi et al. [18], who conducted development research up to the validity test stage by expert validators. Likewise, research on the development of Rahmawati et al. [19] was conducted until the validity test by expert validators to determine the feasibility of the product being developed.

\section{CONCLUSION}

Based on the analysis of research data, it was concluded that learning media and instruments based on the 5E learning cycle model on harmonic vibration material were suitable to be used to improve students' critical thinking skills in 
Physics and based on percentage agreement analysis for the syllabus, Lesson Plan, LKPD and instrument were declared reliable.

\section{REFERENCES}

[1] Fathurrohman, M. (2015). Model-Model Pembelajaran Inovatif. Jogjakarta: Ar- Ruzz Media.

[2] Wagner, T. (2010). Overcoming The Global Achievement Gap (online). Cambridge, Mass., Harvard University.

[3] Sanjaya, W. (2009). Strategi Pembelajaran Berorientasi Standar Proses Pendidikan. Jakarta: Kencana Prenada Media Group.

[4] Zubaidah, S. (2017). Keterampilan Abad ke-21 Keterampilan yang Diajarkan Melalui Pembelajaran. Conference Paper Seminar Nasional Pendidikan dengan tema"Isu-isu Strategis Pembelajaran MIPA Abad 21. Program Studi Pendidikan Biologi STKIP Persada Khatulistiwa Sintang Kalimantan Barat. 1-18.

[5] Shofiah, S., Lukito, A., \& Siswono, T. Y. E. (2018). Pembelajaran Learning Cycle $5 E$ Berbasis Pengajuan Masalah untuk Meningkatkan Hasil Belajar Siswa Kelas X pada Topik Trigonometri. Jurnal Matematika KeatifInovatif, 9 (1): 54-62.

[6] Pesman, H. (2015). Interaction of Student Motivation with Contextual Approach and 5e Learning Cycle in Physics. Universitepark Bulten, 4(1), 16-22.

[7] Hikmawati, H. (2015). Pembelajaran Fisika dengan Model Siklus Belajar 5E (Engage, Explore, Explain, Elaborate, Evaluate) Sebagai Upaya Meningkatkan Kecakapan Hidup Peserta didik. Jurnal Pendidikan Fisika dan Teknologi, 1 (1), 24-37.

[8] Facione, P. A. (2011). Critical Thinking: What it is and Why it Counts. Milbrae: California Academic Press.

[9] Cahyadi, R. A. H. (2019). Pengembangan Bahan Ajar Berbasis ADDIE Model. Education Journal, (3), 35-43.

[10] Suyanto, E., \& Sartinem, E. (2009). Pengembangan Contoh Lembar Kerja Fisika Siswa dengan Latar Penuntasan Bekal Awal Ajar Tugas Studi Pustaka dan Keterampilan Proses untuk SMA Negeri 3 Bandar Lampung. Prosiding Seminar Nasional Pendidikan. Bandar Lampung: Universitas Lampung.

[11] Lestari, D. N., \& Suliyanah, S. (2020). Validitas Perangkat Pembelajaran Fisika Model PredicObserve-Explain (POE) untuk Meningkatkan Keterampilan Berpikir Kritif Fisika Peserta Didik. Jurnal Inovasi Pendidikan Fisika, 09 (2), 157-165.

[12] Borich, G. D. (1994). Observation Skill for Effective Teaching. USA: Macmillan Publishing Company.
[13] Amir, M., Muris, M., \& Arsyad, M. (2015). Pengembangan Perangkat Pembelajaran Berbasis Pengalaman pada Peserta Didik Kelas XI IPA SMA Negeri 9 Pinrang. Jurnal Sains dan Pendidikan Fisika. 11(3): 202213.

[14] Fatmawati, A. (2016). Pengembangan Perangkat Pembelajaran Konsep Pencemaran Lingkungan Menggunakan Model Pembelajaran Berdasarkan Masalah untuk SMA Kelas X. EduSains, 4(2), 94-103.

[15] Andriyatin R., Rosidin, U., \& Suana, W. (2016). Pengembangan Lembar Kerja Siswa Model Problem Based Learning Materi Suhu dan Kalor. Jurnal Pembelajaran Fisika, 4(3): 39-50.

[16] Arikunto, S. (2010). Prosedur Penelitian Suatu Pendekatan Praktik. Jakarta: Rineka Cipta.

[17] Sugiyono, S. 2016. Metode Penelitian Kuantitatif Kualitatif dan $R \& D$. Bandung: Alfabeta.

[18] Dewi, S. M., Gunawan, G., Susilawati, S., \& Harjono, A. (2019). Validitas Perangkat Pembelajaran Fisika Berbasis Model Generatif Berbantuan Laboratorium Virtual. Jurnal Pendidikan Fisika dan Teknologi, 5(1):162-166.

[19] Rahmawati, M., Sutrio, S., Makhrus, M. (2020). Pengembangan Perangkat Pembelajaran Model Reasoning And Problem Solving Dalam Meningkatkan Kemampuan Pemecahan Masalah Fisika Peserta Didik. J. Pijar MIPA, Vol. 15 No.5, November 2020:445-451. 